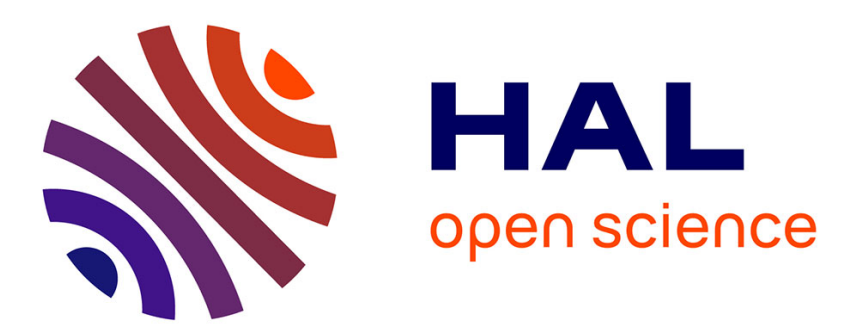

\title{
Superconducting properties and microstructure of Bi2Sr2Ca2Cu3O10 prepared by oxidation of a liquid quenched alloy precursor
}

\author{
J.S. Luo, D. Michel, J.-P. Chevalier
}

\section{- To cite this version:}

J.S. Luo, D. Michel, J.-P. Chevalier. Superconducting properties and microstructure of Bi2Sr2Ca2Cu3O10 prepared by oxidation of a liquid quenched alloy precursor. Revue de Physique Appliquée, 1990, 25 (1), pp.3-7. 10.1051/rphysap:019900025010300 . jpa-00246159

\section{HAL Id: jpa-00246159 https://hal.science/jpa-00246159}

Submitted on 1 Jan 1990

HAL is a multi-disciplinary open access archive for the deposit and dissemination of scientific research documents, whether they are published or not. The documents may come from teaching and research institutions in France or abroad, or from public or private research centers.
L'archive ouverte pluridisciplinaire HAL, est destinée au dépôt et à la diffusion de documents scientifiques de niveau recherche, publiés ou non, émanant des établissements d'enseignement et de recherche français ou étrangers, des laboratoires publics ou privés. 
Classification

Physics Abstracts

$74.70-81.40 \mathrm{R}$

\title{
Superconducting properties and microstructure of $\mathrm{Bi}_{2} \mathrm{Sr}_{2} \mathrm{Ca}_{2} \mathrm{Cu}_{3} \mathrm{O}_{10}$ prepared by oxidation of a liquid quenched alloy precursor
}

\author{
J. S. Luo, D. Michel and J.-P. Chevalier \\ C.E.C.M.-C.N.R.S., 15 rue G. Urbain, F94407 Vitry Cedex, France \\ (Reçu le 28 juin 1989, révisé le 9 octobre 1989, accepté le 10 octobre 1989)
}

\begin{abstract}
Résumé. - Nous avons préparé une phase superconductrice $\mathrm{Bi}_{2} \mathrm{Sr}_{2} \mathrm{Ca}_{2} \mathrm{Cu}_{3} \mathrm{O}_{10}$ à partir d'un alliage précurseur hypertrempé. Après oxydation et recuit à l'air de fragments de l'alliage $\mathrm{Bi}_{2} \mathrm{Sr}_{2} \mathrm{Ca}_{2} \mathrm{Cu}_{3}$, la phase 2223 est principalement ( $>80 \%$ ) obtenue. Sa structure est pseudo-quadratique avec $a=0,3814 \mathrm{~nm}$ et $c=3,702 \mathrm{~nm}$; une modulation selon la direction [110] a été mise en évidence. Le début de la décroissance de la résistivité électrique apparaît à $115 \mathrm{~K}$, mais une résistance nulle n'est atteinte qu'à $25 \mathrm{~K}$ après recuit à l'air et à $70 \mathrm{~K}$ après traitement ultérieur sous oxygène à $400^{\circ} \mathrm{C}$. Différents défauts observés lors d'études microstructurales, ainsi que la stœchiométrie de la phase 2223, peuvent expliquer les variations de résistivité observées.
\end{abstract}

\begin{abstract}
We have produced the $\mathrm{Bi}_{2} \mathrm{Sr}_{2} \mathrm{Ca}_{2} \mathrm{Cu}_{3} \mathrm{O}_{10}$ phase by oxidation of a rapidly quenched alloy precursor. Metallic fragments of $\mathrm{Bi}_{2} \mathrm{Sr}_{2} \mathrm{Ca}_{2} \mathrm{Cu}_{3}$ are prepared by planar flow casting. After oxidation and annealing in air, the 2223 phase is the major constituent obtained $(>80 \%)$. The structure is pseudo-tetragonal with $a=0.3814 \mathrm{~nm}, c=3.702 \mathrm{~nm}$, and we also observe a modulation along the [110] direction. The superconducting onset temperature is at $115 \mathrm{~K}$ and zero resistance is reached at $\sim 25 \mathrm{~K}$ after treatment in air and $\sim 70 \mathrm{~K}$ after treatment under oxygen at $400^{\circ} \mathrm{C}$. Microstructural studies suggests that various defects as well as the stoichiometry of the 2223 phase may explain the aspect of the transitions in the resistivity data.
\end{abstract}

\section{Introduction.}

Since the discovery of superconductivity in the Bi$\mathrm{Sr}-\mathrm{Cu}-\mathrm{O}$ system [1], the transition temperature has been raised from $\sim 20 \mathrm{~K}$ to $\sim 80 \mathrm{~K}$ and then to $\sim 110 \mathrm{~K}$ by addition of calcium [2]. The increase in $T_{\mathrm{c}}$ can be correlated to the number of $\mathrm{CuO}$ layers in the $\mathrm{Bi}_{2} \mathrm{Sr}_{2} \mathrm{Ca}_{n-1} \mathrm{Cu}_{n} \mathrm{O}_{x}$ structural family when $n$ varies from 1 to 3 . For $n=1$ and $n=2$, single phases have been successfully prepared by solid state reaction [3], and their structures have been determined from single crystals $[4,5]$. It is much more

$$
\mathrm{r} n=
$$

which is generally only found in intergrowth with the 2201 and 2212 phases. Tallon et al. [3] obtained only about $20 \%$ of 2223 phase from stoichiometric starting materials. Tarascon et al. [6] succeeded in isolating 2223 cryptocrystals from samples of nominal composition 4334 sintered near $885^{\circ} \mathrm{C}$. Recently, the substitution of lead for bismuth was reported to stabilize the 2223 phase and to increase its proportion $[7,8]$. In most cases, however, extra peaks revealing secondary phases are detected from X-ray diffraction (XRD).
In this work, we prepare superconducting $\mathrm{Bi}_{2} \mathrm{Sr}_{2} \mathrm{Ca}_{2} \mathrm{Cu}_{3} \mathrm{O}_{10}$ by oxidation of a rapidly solidified alloy precursor. If a solubility domain exists for the alloy in the liquid phase, this method has the advantage of ensuring a good chemical homogeneity. This is of special interest for multicomponent phases such as the bismuth superconductors.

The process essentially consists of three steps : firstly melting the metallic constituents to form a homogeneous alloy, secondly, rapidly solidifying the alloy by planar flow casting [9] and finally oxidizing the precursor to the oxide.

is met $o$ as een use to pro uce $t$ e superconducting phases $\mathrm{La}_{1.85} \mathrm{Ba}_{0.15} \mathrm{CuO}_{y}$ [10] and $\mathrm{ReBa}_{2} \mathrm{Cu}_{3} \mathrm{O}_{y}(\mathrm{Re}=\mathrm{Y}, \mathrm{Eu}, \mathrm{Yb})$ [11-13]. In particular, for $\mathrm{EuBa}_{2} \mathrm{Cu}_{3} \mathrm{O}_{y}$, the chemical homogeneity is found to be improved and the microstructure more uniform than in materials prepared from usual ceramic processes. This results in a higher critical current density [13]. We have also succeeded, using the same method, in obtaining single phase $\mathrm{Bi}_{4} \mathrm{Sr}_{3} \mathrm{Ca}_{3} \mathrm{Cu}_{4} \mathrm{O}_{y}$ [13], and in producing a majority 2223 phase by oxidizing the $\left(\mathrm{Bi}_{0.7} \mathrm{~Pb}_{0.3}\right)_{2} \mathrm{Sr}_{2} \mathrm{Ca}_{2} \mathrm{Cu}_{3}$ alloy precursor [14]. 


\section{Experimental procedure.}

Alloys pellets of $\sim 4 \mathrm{~g}$ are prepared from the constituents in the $2: 2: 2: 3$ proportions by radio frequency (RF) melting in a water cooled copper hearth under flowing helium. These are then introduced in the quartz glass tube of the planar flow casting system. The tube nozzle used is a slit $(0.5 \mathrm{~mm} \times 10 \mathrm{~mm})$ positioned at $0.1 \sim 0.15 \mathrm{~mm}$ from the $300 \mathrm{~mm}$ diameter copper-chromium wheel surface (rotation speed $1200 \mathrm{rpm}$ ). The alloy is heated by RF induction and the whole assembly is in a large tank under a helium atmosphere. An optical pyrometer is used to determine the casting temperature (around $1400^{\circ} \mathrm{C}$ ). The rapidly quenched alloys are unfortunately extremely brittle, and thus we are only able to recover fragments. After quenching, the tank is opened and these are brushed into a dish containing hexane. Despite these precautions, some fragments are heavily oxidized at this stage.

Differential thermal analysis and thermogravimetry experiments enable us to choose appropriate oxidation conditions. Samples are thus maintained for 25 hours close to $820^{\circ} \mathrm{C}$ before furnace cooling to room temperature. A platinum sheet prevents the alumina crucible from eventually contaminating the sample. The oxidized fragments are then ground, compacted and sintered at $870{ }^{\circ} \mathrm{C}$ in air for 200 hours and finally air-quenched. Repeated grinding between sintering steps is found necessary to obtain the 2223 phase.

XRD spectra (filtered Co $\mathrm{K}_{\alpha}$ radiation) are recorded using a Philips diffractometer. The lattice parameters are refined by means of a least squares program. The final superconducting oxide is examined on its fracture surface by scanning electron microscopy (SEM) with a ZEISS DSM950 equipped with TRACOR X-ray microanalysis. Transmission electron microscopy (TEM) is performed using a JEOL 2000FX on samples prepared by argon ion milling.

Resistivity measurements are carried out on bars (approximately $2 \mathrm{~mm} \times 2 \mathrm{~mm} \times 10 \mathrm{~mm}$ ) cut from as-sintered samples. A standard four probe dc method is used with silver paint contacts. The measurement current is $10 \mathrm{~mA}$. In the superconducting state, the maximum detected potential difference is smaller than $1 \mu \mathrm{V}$ and does not change in sign when the current is reversed.

\section{Results.}

Alloys with $\mathrm{Bi}_{2} \mathrm{Sr}_{2} \mathrm{Ca}_{2} \mathrm{Cu}_{3}$ composition have been quenched into $\sim 30 \mu \mathrm{m}$ thick foil fragments. Casting is found difficult due to the formation of an intermetallic compound $\mathrm{Bi}_{2}\left(\mathrm{Sr}_{x} \mathrm{Ca}_{1-x}\right)_{2}$ with a high melting point $\left(>1200^{\circ} \mathrm{C}\right)$ [13]. XRD mainly shows a broad maximum typical of an amorphous phase. In addition, broad peaks of $\mathrm{CaCu}_{5}, \mathrm{Bi}_{10} \mathrm{Ca}_{11}, \mathrm{Bi}$ and
$\mathrm{Cu}$ are detected. These may arise from crystallization and phase separation on solidification. After oxidation at $820^{\circ} \mathrm{C}$ in air, these fragments predominantly yield the 2212 phase with no traces of the 2223 phase in XRD. This suggests that the 2212 phase is more stable at lower temperatures, at least for kinetic reasons. The 2223 phase only appears through annealing at $870{ }^{\circ} \mathrm{C}$. The annealing temperature is found to be very critical in order to produce the 2223 phase, and intermediate regrinding is necessary because of the sluggish diffusion process. We did not succeed in directly obtaining the 2223 phase by alloy oxidation at $870{ }^{\circ} \mathrm{C}$ due to partial melting of the sample. It is thus important to oxidize the sample prior to annealing at this temperature.

After annealing $\sim 200$ hours and then quenching into air, XRD shows that the resulting oxide is essentially 2223 and this has a pseudo-tetragonal structure $(a=0.3814 \mathrm{~nm}, c=3.702 \mathrm{~nm})$. Narrow diffraction peaks indicate a good crystallinity of the phase (Fig. 1). In fact, as for 2212 [16], the unit cell derived from TEM diffraction is orthorhombic with $a^{\prime}$ and $b^{\prime}=a \sqrt{2}$ corresponding to the [110] distance of the perovskite cell. The extra peaks marked by arrows in figure 1 are due to the 2201 phase. Prolonged heat treatment does not decrease their intensity. This means that some adjustment of the starting composition would be necessary to obtain a pure phase.

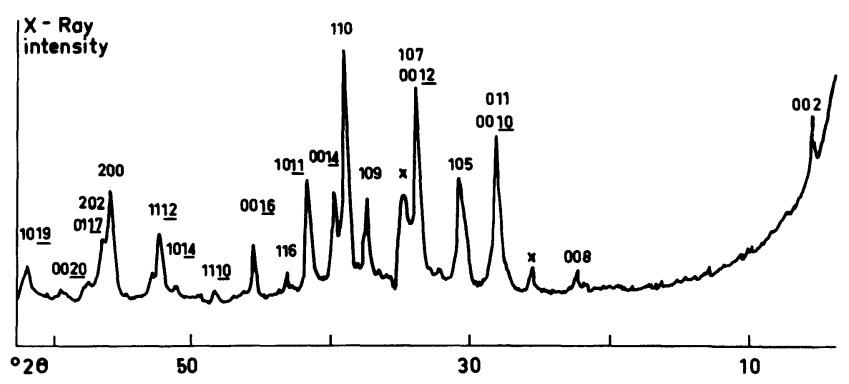

Fig. 1. - X-ray powder diffraction spectrum of the sample prepared from a rapidly quenched precursor alloy $\mathrm{Bi}_{2} \mathrm{Sr}_{2} \mathrm{Ca}_{2} \mathrm{Cu}_{3}$ ( $\mathrm{CoK}_{\alpha}$ radiation). Extra lines(x) correspond to $\mathrm{Bi}_{2} \mathrm{Sr}_{2} \mathrm{CuO}_{y}$. The background at low angles is due to the tail of the direct beam and not to an amorphous phase.

Our results show that samples consisting mainly of the 2223 phase can be prepared without lead addition. Comparing with previous results on $\mathrm{Pb}$ doped samples [14], it seems that lead acts not only as a substituent atom in the superconductor, but also as a flux accelerating the sintering and reaction kinetics, since the 2223 phase is obtained after only $\sim 25$ hours annealing at similar temperatures [14]. This is also suggested by the fact that the melting point of $\mathrm{Ca}_{2} \mathrm{PbO}_{4}\left(822^{\circ} \mathrm{C}\right)$, a compound which 
often appears in $\mathrm{Pb}$ added $\mathrm{Bi}-\mathrm{Sr}-\mathrm{Ca}-\mathrm{Cu}-\mathrm{O}$, is below the annealing temperature [15]. In the case of the oxide prepared from an alloy precursor, it is likely that the higher reactivity of the product enables the formation of the 2223 phase.

Figure 2 shows the temperature dependence of the resistivity of our sample after air quenching from $870^{\circ} \mathrm{C}$. The initial drop in resistivity occurs near $115 \mathrm{~K}$, which is the reported value for the superconducting transition of the 2223 phase [3]. However, the transition is very broad and zero resistance is only reached at $\sim 25 \mathrm{~K}$. An anomalous transition observed around $75 \mathrm{~K}$ suggests the presence of the 2212 phase, even though no trace is detected by XRD. We notice that the curve slope from room temperature to $T_{\mathrm{c}}$ (onset) is negative. It is possible that this semiconductor-like behaviour arises from the oxygen stoichiometry which has not been optimized. Annealing treatments under oxygen at $400{ }^{\circ} \mathrm{C}$ for 40 hours actually induces significant modification of the resistivity behaviour as shown in figure $2 \mathrm{~b}$. In this case, the room temperature resistivity is much lower by more than one order of magnitude, the positive slope indicates now a metallic type behaviour above the superconducting transition. Zero resistance is obtained at $\sim 70 \mathrm{~K}$ but

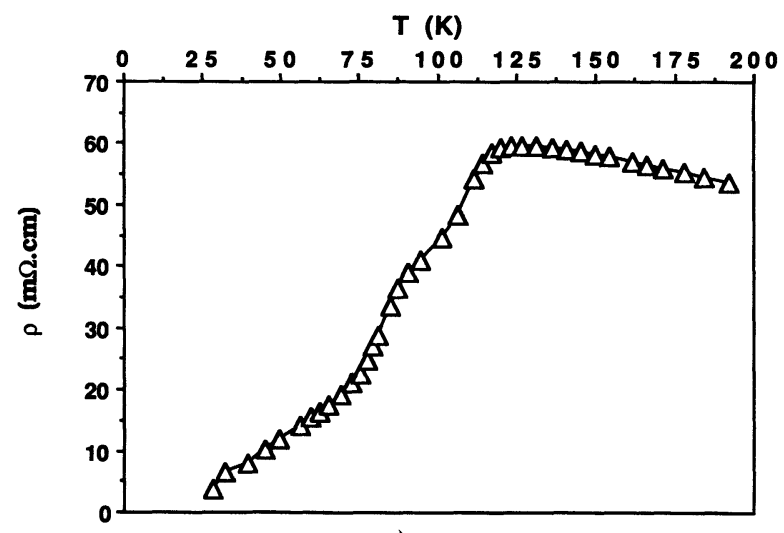

a)

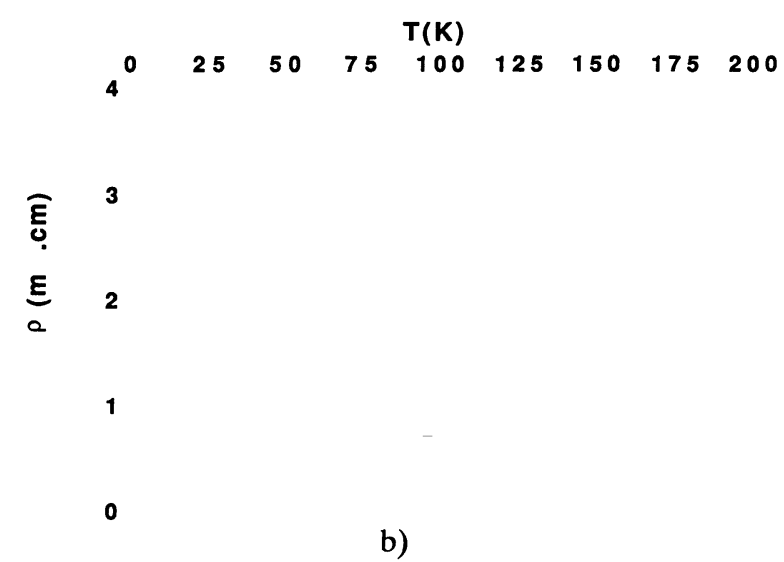

Fig. 2. - Resistivity curves of the superconducting oxide prepared from a rapidly quenched precursor alloy $\mathrm{Bi}_{2} \mathrm{Sr}_{2} \mathrm{Ca}_{2} \mathrm{Cu}_{3}$ : a) annealing in air at $870{ }^{\circ} \mathrm{C}$; b) same sample after subsequent annealing in oxygen at $400^{\circ} \mathrm{C}$. with a sharper decrease in resistivity around $110 \mathrm{~K}$. Electrical properties seems to be thus markedly influenced by oxygen stoichiometry despite the fact that there is no noticeable difference between the diffraction diagram before and after treatment in oxygen.

SEM examination of as-sintered samples on their fracture surface reveals the plate-like morphology typical of most $\mathrm{Bi}-\mathrm{Sr}-\mathrm{Ca}-\mathrm{Cu}-\mathrm{O}$ superconductors (Fig. 3). The grain size distribution is found to be rather homogeneous with an average value of about $8 \mu \mathrm{m}$. No phase with a morphology different from the layered one is observed and the surface of the platelets seems clean. However, an amorphous phase can be seen by TEM examination at some grain boundaries (Fig. 4). This figure also shows that

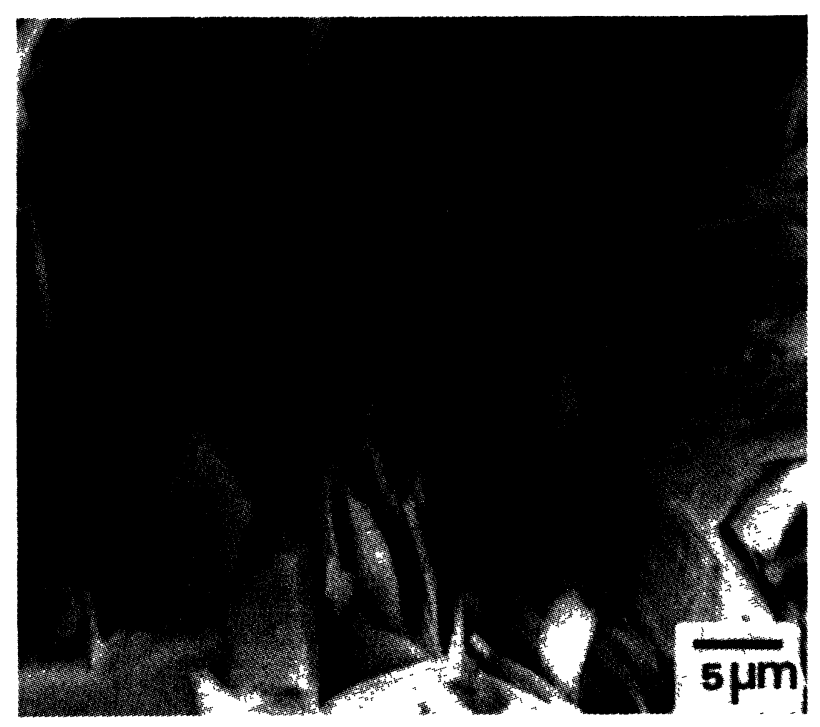

Fig. 3. - SEM image of the oxide prepared from a rapidly quenched alloy precursor $\mathrm{Bi}_{2} \mathrm{Sr}_{2} \mathrm{Ca}_{2} \mathrm{Cu}_{3}$ showing the platelike morphology which is characteristic of $\mathrm{Bi}-\mathrm{Sr}-\mathrm{Ca}-\mathrm{Cu}-\mathrm{O}$ compounds.

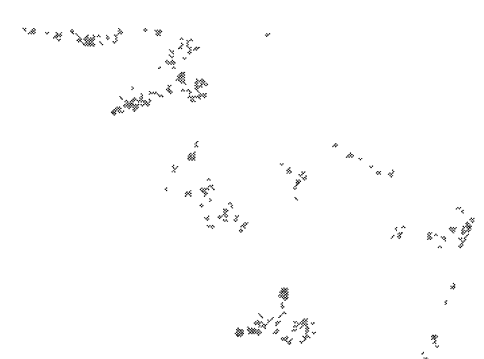

Fig. 4. - TEM image showing small angle boundaries and an amorphous phase at a grain boundary. 


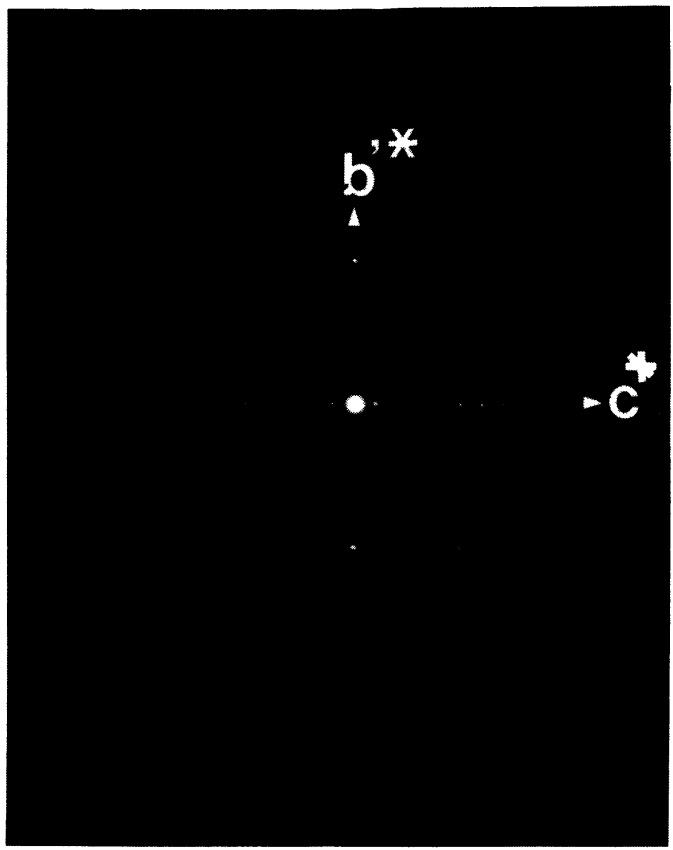

a)

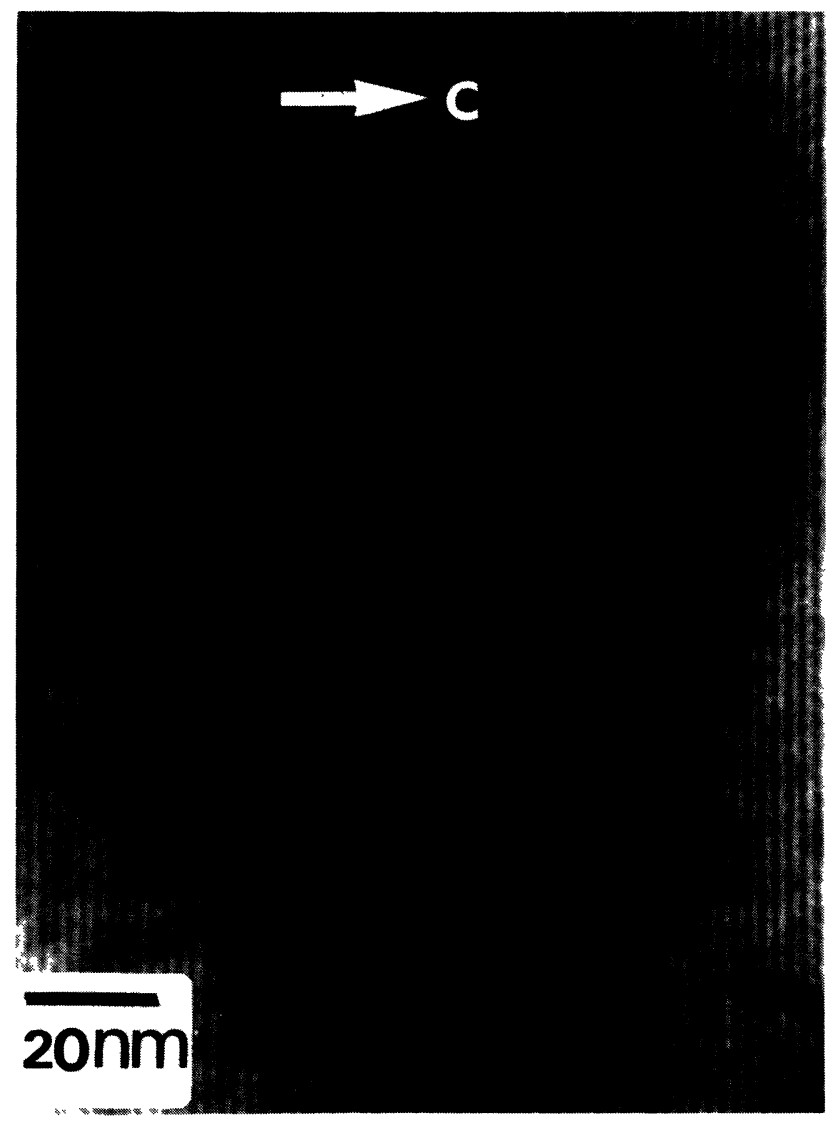

b)

Fig. 5. - a) Electron diffraction pattern showing the $3.8 \mathrm{~nm}$ c-parameter of 2223 and a modulation along $\mathbf{b}^{\prime}$. The wave vector $4.75 \pm 0.05\left|\mathbf{b}^{\prime}\right|$ is similar to that found for the 2212 phase [16, 17]. b) TEM image of a defect-free zone of 2223. The spacing of vertical fringes is $1.9 \mathrm{~nm}$ (half the $\mathbf{c}$ value) and the vertical modulation of $2.56 \mathrm{~nm}$ is observed ( 4.75 times the $\mathbf{b}^{\prime}$ value). adjacent grains have generally the same direction for their c axis with eventually a small-angle misorientation around this direction.

The spacing along the c axis shows that the 2223 phase is the major constituent of the sample. A regular value of $\sim 1.9 \mathrm{~nm}$ (half of $3.7 \mathrm{~nm}$ ) is representative of the majority of our samples (Fig. 5a). However, inside 2223 zones, local variation of c spacing indicates intergrowth with parent layer phases. In particular, small blocks of the 2201 phase detected by XRD are observed between the 2223 phase in many grains as shown in figure 6 . These defects are probably involved in the electrical behavior and it is possible that they broaden the superconducting transition.

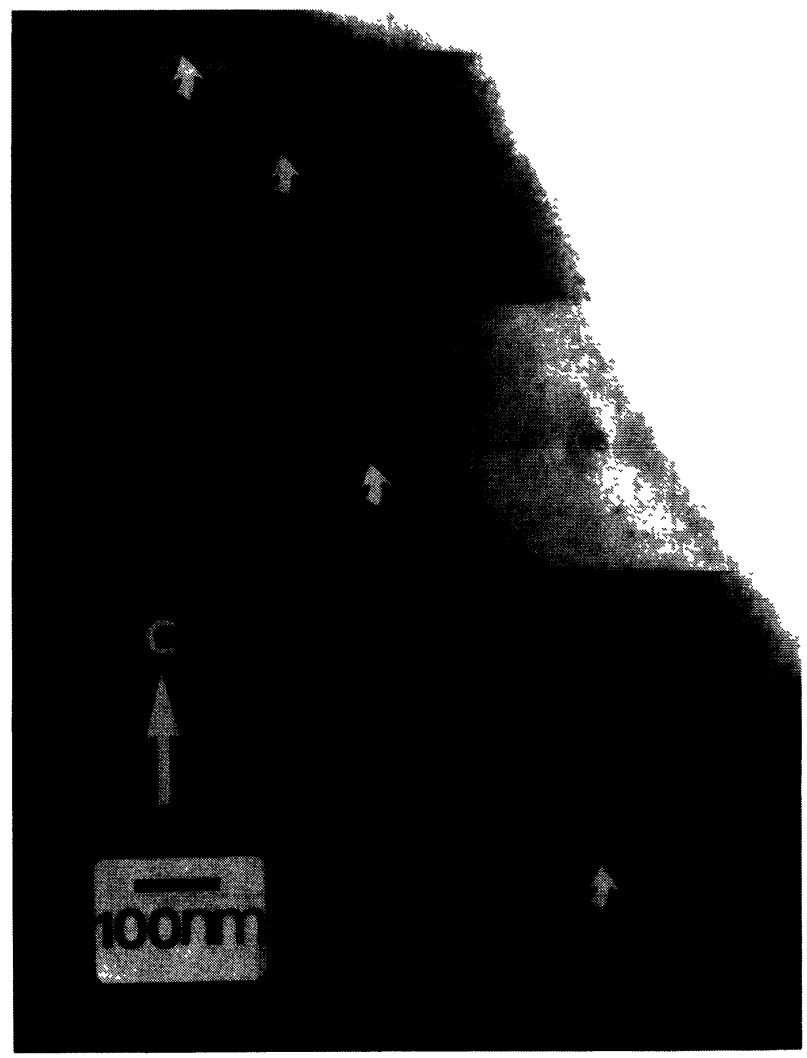

Fig. 6. - TEM image showing defects in the stacking sequence perpendicular to $c$ within the 2223 host phase. The c spacings of these blocks correspond mainly to 2201 and occasionally to 2212 in agreement with X-ray diffraction results.

\section{Conclusion.}

We have prepared the $\mathrm{Bi}_{2} \mathrm{Sr}_{2} \mathrm{Ca}_{2} \mathrm{Cu}_{3} \mathrm{O}_{10}$ phase using a rapidly quenched alloy precursor. The method of planar flow casting apparently enhances the reactivity of the starting product and ensures a homogeneous cation distribution. Slight modification in the starting 
composition would be required to obtain a rigorously single phase product. Resistivity measurements indicate a $T_{\mathrm{c}}$ onset near $115 \mathrm{~K}$ for the 2223 phase. TEM microstructural observations in combination with electron diffraction confirm that the phase is characterized by a c parameter of $\sim 3.7 \mathrm{~nm}$ and that a structural modulation is present along the $\mathbf{b}^{\prime}$ direction. Furthermore, intergrowths with 2212 and 2101 stacking sequences are commonly observed.

Because of the plate-like morphology of grains, defects along c axis may strongly affect the electrical transport. Intergrowth with other stacking sequences may explain the broad superconducting transition observed in our samples despite the relative purity of the 2223 phase. Oxygen stoichiometry is also found to be an important parameter since an oxygen annealing atmosphere improves superconducting properties. The presence of an amorphous phase at grain boundaries is likely to affect the value of the critical current.

\section{Acknowledgments.}

The authors wish to thank A. Dezellus and S. Peynot for essential assistance in both alloy synthesis and rapid quenching. We are also grateful to the CNRS (ARC «Microstructure des nouveaux supraconducteurs ») and to Rhône-Poulenc for financial support.

\section{References}

[1] Michel C., Hervieu M., Borel M. M., Grandin A., Deslandes F., Provost J. and Raveau B., Z. Phys. B 68 (1987) 421.

[2] Maeda M., Tanaka Y., Fukutomi M. and Asano T., Jpn J. Appl. Phys. Lett. 27 (1988) L209.

[3] Tallon J. L., Buckley R. G., Gilberd P. W., Presland M. R., Brown I. W. M., Bowden M. E., Christian L. A. and Goguel R., Nature 333 (1988) 153.

[4] Torardi C. C., Subramanian M. A., Calabrese J. C., Gopalakrishnan J., McCarron E. M., MorrisSEy K. J., ASKeW T. R., FLIPPEN R. B., Chowdhry U. and Sleight A. W., Phys. Rev. B 38 (1988) 225.

[5] Subramanian M. A., Torardi C. C., Calabrese J. C., Gopalakrishnan J., MorrisSey K. J., ASKew T. R., Flippen R. B., CHOWDHRY U. and Sleight A. W., Science 239 (1988) 1015.

[6] Tarascon J. M., McKinnon W. R., Barboux P., Hwang D. M., Bagley B. G., Greene L. H., Hull G. W., Lepage Y., Stoffel N. and Giroud M., Phys. Rev. B 38 (1988) 8885.

[7] Sunshine S. A., Siegriet T., SChNEEMEyer L. F., Murphy D. W., CaVa R. J., Baltlogg B., VAN Dover R. B., Fleming R. M., Glarum
S. H., NaKahara S., Farrow R., KRajewski J. J., ZahuraK S. M., WaszczaK J. V., MARShall J. H., MARSh P., RUPP L. W. Jr and PeCK W. F., Phys. Rev. B 38 (1988) 893.

[8] Green S. M., Jiang C., Yu Mei, Luo H. L. and Politis C., Phys. Rev. B 38 (1988) 5016.

[9] Narasimhan M., Patent U. S. 4 (1979) 142, 571.

[10] Matsuzaki K., InOue A., Kimura H., Moroishi K. and MAsumoto T., Jpn J. Appl. Phys. Lett. 26 (1987) L334.

[11] Haldar R., Lu Y. Z. and Giessen B. C., Appl. Phys. Lett. 51 (1987) 538.

[12] YAVARI A. R. and Weiss F., Europhys. Lett. 4 (1987) 1315.

[13] Luo J. S., Chevalier J.-P. and Michel D., Mater. Sci. Eng. B 3 (1989) 325.

[14] Luo J. S., Chevalier J.-P. and Michel D., Appl. Phys. Lett. (in press).

[15] Kijima N., Endo H., Tsuchiya J., Sumiyama A., Mizuno M. and Oguri Y., Jpn J. Appl. Phys. Lett. 27 (1988) L1852.

[16] Shaw T. M., Shivashankar S. A., La Placa S. J., CuOMO J. J., RoY T. R., KELleher K. H. and YeE D. S., Phys. Rev. B 37 (1988) 9856.

[17] Hewat E. A., J. Micros. Electron. 13 (1988) 297. 